Biofilmed biofertilizers for improved quality and quantity of strawberry (Fragaria ananassa) under field conditions

I.D. Singhalage ${ }^{*}$, G. Seneviratne and H.M.S.P. Madawala
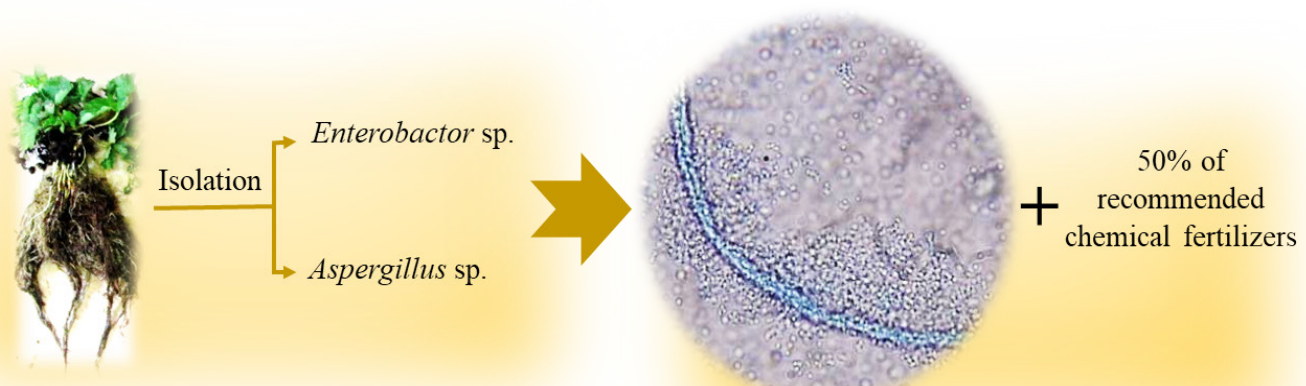

Rhizosphere of Fragaria ananassa (Strawberry)

Fungal bacterial biofilm in between Enterobactor sp. and Aspergillus sp

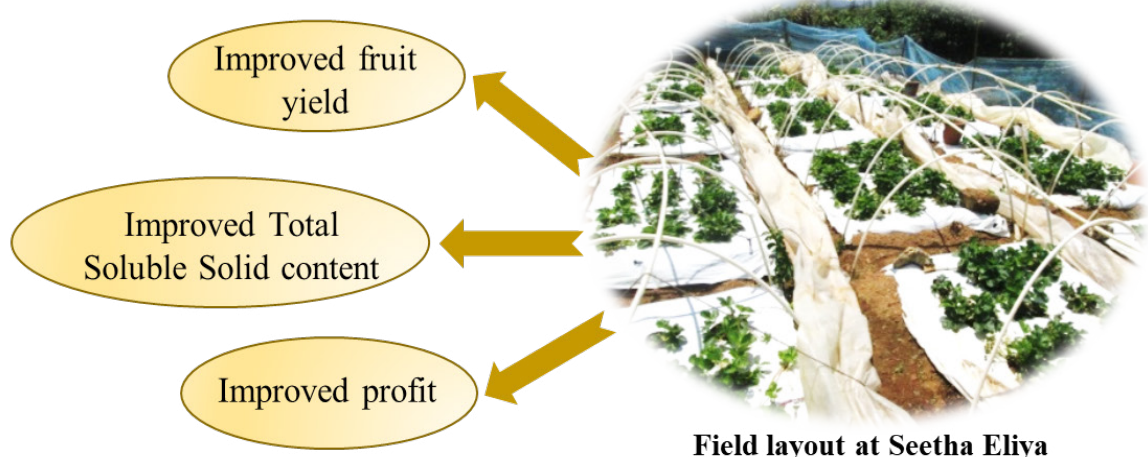

Field layout at Seetha Eliya Agricultural Research Station

\title{
Highlights
}

- Strawberry yield under the application of Biofilmed Biofertilizer (BFBFs) was studied.

- The highest fruit yield, count and size per plant were obtained in BFBF with 50\% Chemical Fertilizers (CFs).

- The BFBF $+50 \%$ CFs practice was ca. $30 \%$ more profitable than the $100 \%$ CFs alone practice. 


\title{
RESEARCH ARTICLE
}

\section{Biofilmed biofertilizers for improved quality and quantity of strawberry (Fragaria ananassa) under field conditions}

\author{
I.D. Singhalage ${ }^{1,3, *}$, G. Seneviratne ${ }^{1}$ and H.M.S.P. Madawala ${ }^{2}$ \\ ${ }^{1}$ Microbial Biotechnology Unit, National Institute of Fundamental Studies, Kandy, Sri Lanka. \\ ${ }^{2}$ Department of Botany, Faculty of Science, University of Peradeniya, Peradeniya, Sri Lanka. \\ ${ }^{3}$ Department of Science and Technology, Faculty of Applied Sciences, Uva Wellassa University of Sri Lanka, Badulla, \\ Sri Lanka.
}

Received: 30/10/2020; Accepted: 01/05/2021

\begin{abstract}
In order to reduce high doses of chemical fertilizers (CFs) used in strawberry, scientists have tested monoculture-based biofertilizers without much success. In recent years, biofilmed biofertilizers (BFBFs) have been used in cash crops successfully while reducing the recommended dosage of CFs up to $50 \%$. A field trial was carried out to evaluate the effects of BFBF, developed using microbial isolates from strawberry rhizosphere (Aspergillus sp. and Enterobacter sp.), on the quantity and quality of strawberry harvest. Strawberry plants were subjected to BFBF only, $\mathrm{BFBF}+50 \% \mathrm{CFs}, 50 \% \mathrm{CFs}$ and $100 \% \mathrm{CFs}$ with nine replicates for each treatment arranged in Randomized Complete Block Design. The control was maintained without BFBF or CFs. BFBF diluted 20 times in water was sprayed on to raised planting beds a week prior to introducing strawberry plants followed by repeated application in two-month intervals. Yield was recorded up to the $30^{\text {th }}$ week. The quality of fruits was analyzed using Total Soluble Solids (TSS), titratable acid and ascorbic acid contents. Diameter of the plant spread (crown) and plant dry weight were measured. Flowering was first observed in plants treated with $\mathrm{BFBF}+50 \% \mathrm{CFs}$. The highest cumulative fruit yield $(109 \mathrm{~g})$, mean fruit count $(14.77 \pm 4.62)$ and fruit size $(6.39$ $\left.\mathrm{cm}^{3} \pm 0.86\right)$ per plant were also observed in the same treatment. The plant spread was found to be a good predictor of the yield. The TSS levels and TSS/acid ratios were significantly higher in all treatments over $100 \% \mathrm{CFs}(\mathrm{p}<0.05)$. The BFBF $+50 \%$ CFs practice were ca. $30 \%$ more profitable than the $100 \% \mathrm{CFs}$ alone. The results confirmed that the BFBF coupled with $50 \%$ $\mathrm{CFs}$ can be recommended over the full dosage of CFs alone for more profitable and highquality strawberry production under field conditions tested. Thus, further studies are needed to introduce BFBF for strawberry under variable soil and climatic conditions.
\end{abstract}

Keywords: Strawberry; biofilmed biofertilizer; chemical fertilizer.

\section{INTRODUCTION}

In conventional strawberry farming, the use of high doses of CFs is a common practice to gain higher fruit yields. In Sri Lanka, the total fertilizer addition for one cropping season of strawberry is $720 \mathrm{~kg} / \mathrm{ha}$ of urea, $400 \mathrm{~kg} / \mathrm{ha}$ of super phosphate and $400 \mathrm{~kg} / \mathrm{ha}$ of muriate of potash (Strawberry Growers Manual, Department of Agriculture, Sri Lanka, 2012). The continuous application of CFs can adversely affect the soil fertility and eventually the yield, due to their deleterious effects on the soil fauna including microbes (Medley et al., 1982; Seneviratne, 2009). The adverse impacts on the soil biota can disrupt the nutrient cycles and breakdown of organic matter in soil. While the list of environmental consequences related to conventional agriculture continues, scientists have directed their attention to explore ways to reduce the usage of CFs by coupling CFs with microbial biofertilizers. This practice has demonstrated positive results with many crops. Soya beans showed a better growth with phosphorus solubilizing bacteria, Bradyrhizobium japonicum coupled with $33 \%$ of CFs (Janagard et al., 2013). Yosefi et al. (2011) demonstrated similar results in maize. Strawberry also benefited from the use of biofertilizers in combination with CFs (Zargar et al., 2008; Umar et al., 2010). According to Zargar et al. (2008), application of nitrogen (225 $\left.\mathrm{kg} \mathrm{ha}^{-1}\right)$, and phosphorus (150 kg ha-1) together with biofertilizer (Azotobacter) has increased the average fruit weight of strawberry. The application of $25 \%$ nitrogen through 'subabul' (green leafy manure of Leucaena leucocephala) along with $75 \%$ $\mathrm{N}$ in the form of urea augmented with biofertilizers has resulted in an improved fruit size and weight in strawberry cv. 'Chandler' (Umar et al., 2010). The use of biofilmed biofertilizers (BFBFs) has reduced the recommended dosages of CFs by $50 \%$ in tea (Seneviratne et al., 2011). In addition, the application of biofertilizers enhanced soil microbial communities by increasing microbial diversity (Pěsaković, 2013; Seneviratne and Kulasooriya, 2013), restoring conventional agricultural soils (Seneviratne et al., 2011) and bio-controlling effects (Saharan and Nehra, 2011; Seneviratne, 2012).

Strawberry (Fragaria ananassa) belongs to the family Rosaceae. Cultivated strawberry, are said to be day-neutrals (Sønsteby and Heide, 2007). Yield, size and shape of strawberry fruit depend mainly on the adequate pollination potential by different insects (Zaitoun et al., 2006). 
Strawberries are cultivated under glasshouse conditions and as well as in open fields. Planted strawberry should be watered in three - day intervals. The fruits are generally harvested $4-4 \frac{1}{2}$ months after planting.

This study was carried out to evaluate the effects of BFBFs, developed from microbes isolated from the strawberry rhizosphere, on the quantity and quality of strawberry harvest under field conditions.

\section{MATERIALS AND METHODOLOGY}

\section{Locations and treatments}

The field experiment was conducted in Seetha Eliya Agricultural Research Station located in the upcountry of Sri Lanka (location: $6^{\circ} 93^{`}-80^{\circ} 81^{\prime}$, altitude: $1868 \mathrm{~m}$, day and night temperature: 20.0 and $11.6{ }^{\circ} \mathrm{C}$, relative humidity: $77 \%$ and light intensity: $1600 \mathrm{lux}$ ). Treatments used in this study were fungal-bacterial BFBF only, BFBF coupled with $50 \%$ of recommended dosage of chemical fertilizers (BFBF $+50 \%$ CFs, this treatment was selected based on the findings of previous biofertilizer experiments), $100 \%$ (reference treatment) and 50\% CFs only. A control was maintained without BFBF or CFs. The BFBF were developed in a low cost medium (LCM) formulated by the Microbial Biotechnology Unit (MBU) of the National Institute of Fundamental Studies (NIFS), Sri Lanka using microbial isolates (Aspergillus sp. and Enterobacter sp.) from the strawberry rhizosphere carried out in a previous study (Singhalage et al., 2019).

\section{Bedding, planting and maintaining treatments}

Fifteen strawberry (Fragaria ananassa var. Chandler) plants from generation 1 (raised in a nursery) were planted in mulched, raised beds $(1.5 \times 0.9 \times 0.2 \mathrm{~m}$, soil pH $6.65 \pm$ 0.19 , moisture $29.67 \pm 1.50 \mathrm{~g} / \mathrm{g}$ soil, available $\mathrm{NO}_{3}^{-} 71.76$ $\pm 0.00 \mu \mathrm{g} / \mathrm{g}$ soil, available $\mathrm{NH}_{4}^{+} 0.05 \pm 0.00 \mu \mathrm{g} / \mathrm{g}$ soil and available $\mathrm{PO}_{4}^{3-} 5.46 \pm 1.00 \mu \mathrm{g} / \mathrm{g}$ soil) with a spacing of 0.3 $\mathrm{x} 0.3 \mathrm{~m}$. This unit is considered as a plot. The growth data were collected from the three plants in the middle of each bed to avoid any edge effects (Figure 1a and 2). There were three main blocks each having five beds with treatments allocated to them randomly. BFBF in LCM, was diluted 20 times in water and sprayed on to raised planting beds at a rate of $500 \mathrm{~mL} / \mathrm{ha}$ a week prior to planting followed by repeated applications in two-month intervals up to 40 weeks. There were nine replicates for each treatment. Archshaped mini tunnels (with $0.75 \mathrm{~m}$ maximum middle point height) were established for each block using white colour polythene (recommended for mini tunnels) to maintain a higher temperature inside the tunnels especially during the nights (Figure 1b). Mini tunnels were kept open during the daytime to facilitate the pollinators (Figure 1c). Plants were watered in 3-day intervals. The plots were arranged in Randomized Complete Block Design (RCBD). Field experiment was maintained for 10 months to make sure that the fruiting period was over after the $30^{\text {th }}$ week.

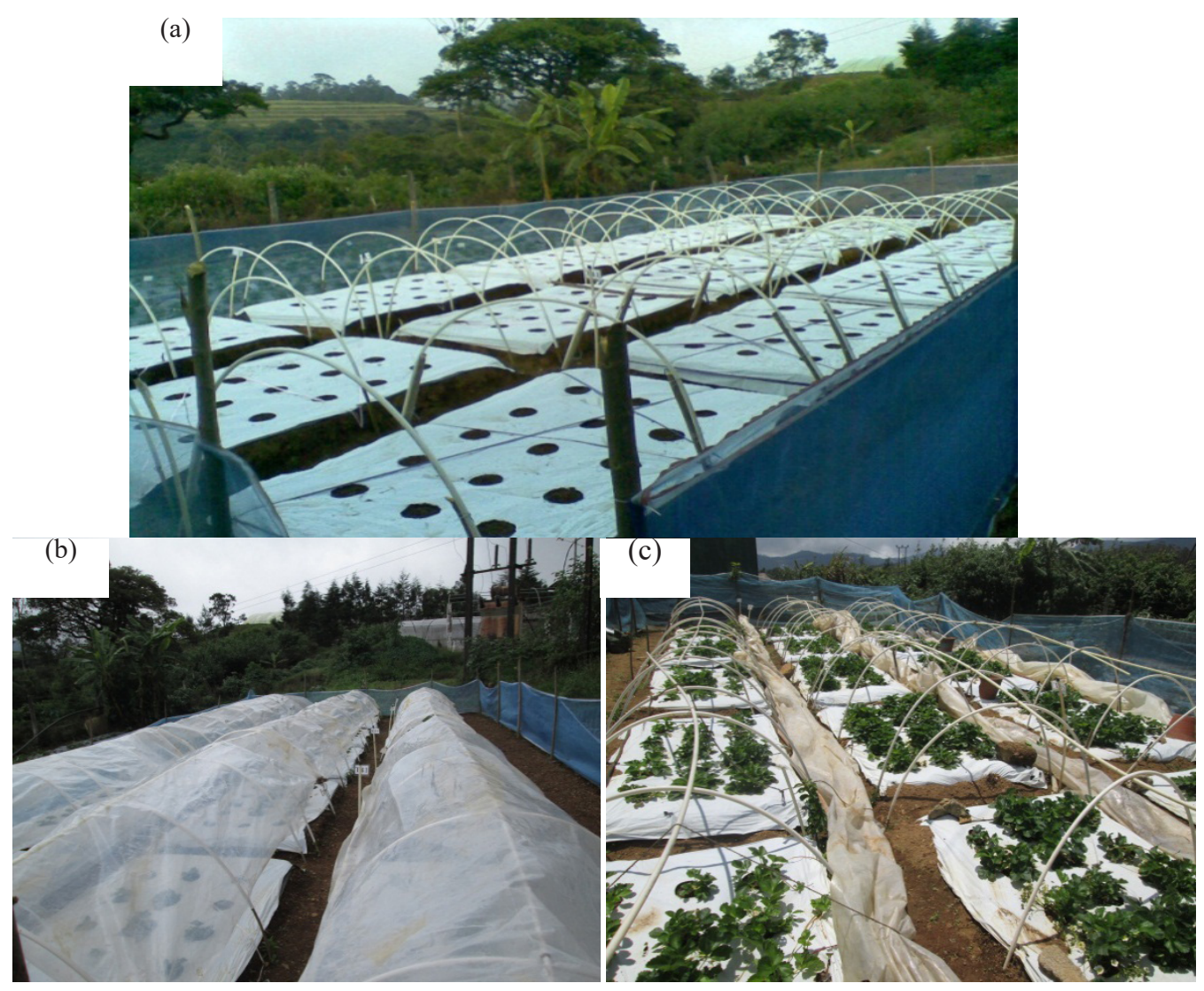

Figure 1: Cultivation practices of strawberry in the field trial. (a) Planting beds prepared at Seetha Eliya Agricultural Research Station after mulching and mini tunneling. Each bed contained fifteen strawberry plants. (b) Covered mini tunnels by polythene. (c) Uncovered mini tunnels during the day time to facilitate the pollinators. 


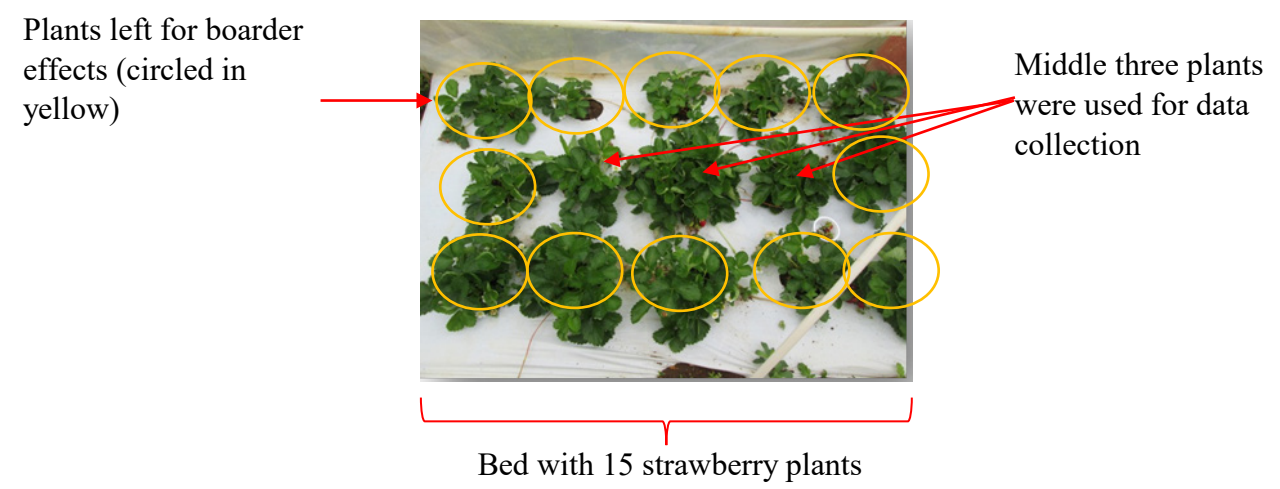

Figure 2: A planting bed showing the 15 strawberry plants. Only the three plants in the middle were used for data collection (in each bed) to avoid the edge effect.

\section{Data collection and analysis}

\section{Growth and yield data}

Diameter of the plant crown (spread) was measured after 4 months and the diameter data were used to calculate the crown area as, $\left.\{\pi \text { (diameter } / 2)^{2}\right\}$. After 6 weeks of planting, flowering and fruiting commenced. The yield data were recorded weekly (number of fruits, their fresh weights and fruit volume) during the first ( $8^{\text {th }}$ to $17^{\text {th }}$ week) and second $\left(26^{\text {th }}\right.$ to $30^{\text {th }}$ week) harvesting cycles. At the end of the field experiment (after 10 months), plants were harvested and dry biomass was recorded to determine the growth performances of plants under each treatment. The yield increase over the control (\%) was calculated as, \{(yield under the treatment - yield under the control)/yield under the control $\} \times 100$.

\section{Quality of fruits}

Samples taken from each harvest were used to analyze total soluble solids (TSS), titratable acids (TA) and ascorbic acid using standard methods. TSS was determined using a handheld refractometer (Atago), while TA and ascorbic acid were determined after extracting to distilled water from fruits with equal stages of colour development, and titrated against $0.1 \mathrm{M} \mathrm{NaOH}$ (phenolphthalein as the indicator) and $0.005 \mathrm{~mol} / \mathrm{L}$ iodine solution (starch as the indicator), respectively. The results were presented as parts per million (ppm) and expressed in fresh weight basis (Ali et al., 2011). The fruit volume was determined by measuring the amount of water replaced in a measuring cylinder after immersing the fruit.

\section{Data analysis}

The growth (plant spread and biomass) and fruit quality (TSS, TA and ascorbic acid) parameters were analyzed using Analysis of Variance (ANOVA) and means were separated by Tukey's simultaneous mean separation test. Strawberry yield was correlated with the growth parameters using Pearson correlation coefficient. Net profits of strawberry production were calculated under each treatment. Statistical analyses were performed in Minitab statistical package (Minitab® 16.2.1, 2010).

\section{RESULTS}

\section{Plant growth}

A higher spread was observed in plants treated with BFBF $+50 \% \mathrm{CF}$ in comparison to the control (Figure 3a). Plants provided with $100 \% \mathrm{CFs}$ or $\mathrm{BFBF}+50 \% \mathrm{CFs}$ showed significantly improved $(\mathrm{p}<0.05)$ plant dry mass than the control (Figure 3b).

\section{Strawberry yield}

Count, weight, and the volume of the strawberry fruits under different fertilizer treatments are given in Table 1. The BFBF $+50 \%$ CFs treatment showed a yield increase of $92 \%$ over the control. It was mainly attributed to fruit volume increase, and hence weight increase. The yield increase of $100 \%$ CFs alone was only $74 \%$.

The fruit counts were nearly equal in all treatment and the control. However, the fruit sizes were larger in treatments of $100 \% \mathrm{CFs}$, BFBFs and BFBFs $+50 \% \mathrm{CFs}$.

Fruit mass of strawberry showed linear relationships with plant spread $(p=0.000)$ and plant dry mass $(p=0.044)$ (Figures $4 \mathrm{a}$ and $4 \mathrm{~b}$ ). It is clear from this that plant spread, a non-destructive measurement is a better predictor of fruit mass than plant dry mass.

\section{Fruit quality}

According to the measured fruit quality parameters, TSS was significantly higher in all treatments than that of $100 \%$ CFs (Figure 5a). Although not significant, concentration of TA was higher in the BFBFs $+50 \%$ CFs treatment in comparison to other treatments except $50 \% \mathrm{CFs}$ (Figure $5 \mathrm{~b})$. The TSS/TA ratio that determines the organoleptic properties of fruit was the lowest in 100\% CFs (Figure 5c). This adversely affects consumer demand of the produce. Higher ascorbic acid contents were detected in fruits of $50 \% \mathrm{CFs}$ and BFBFs $+50 \% \mathrm{CFs}$ (Figure $5 \mathrm{~d}$ ). It is worthy to mention that the organoleptic qualities of the control were similar to $50 \% \mathrm{CFs}$ and $\mathrm{BFBFs}+50 \% \mathrm{CFs}$ at all parameters except in the case of ascorbic acid content. 
(a)

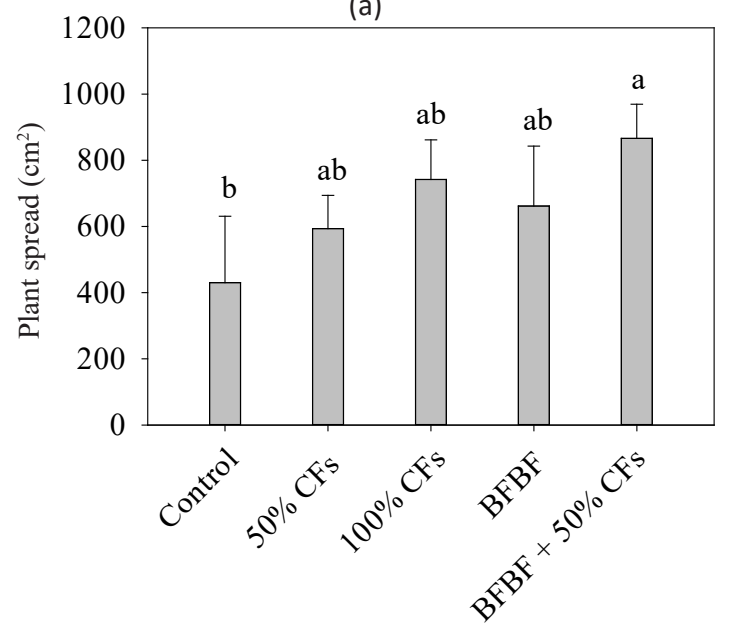

Treatment

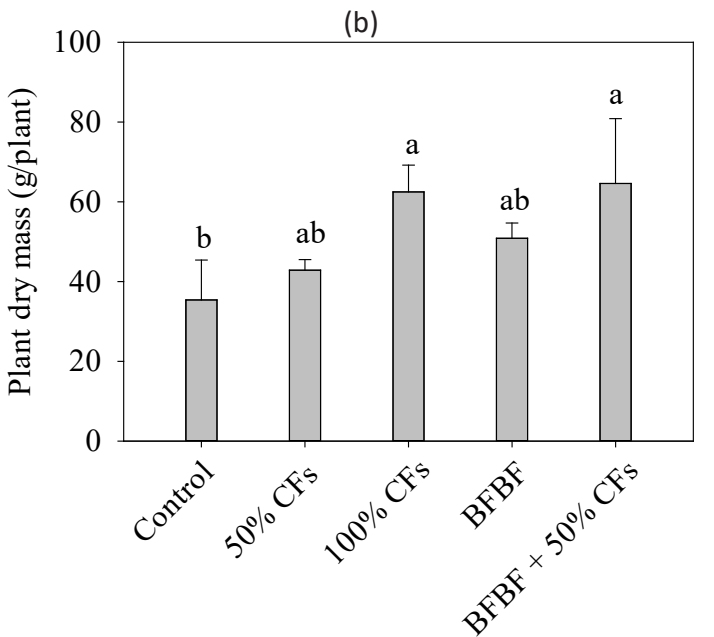

Treatment

Figure 3: Plant spread (a) and dry mass (b) of strawberry under treatments $50 \% \mathrm{CFs}, 100 \% \mathrm{CFs}$, BFBFs, BFBFs $+50 \% \mathrm{CFs}$ and the control. Treatment columns with different letters are significantly different at the 5\% probability level according to the ANOVA.

Table 1: Mean fruit count, mean weight and mean volume ( \pm SEM) of strawberry of different treatments

\begin{tabular}{lcccc}
\hline Treatment & Fruit count/plant & Fruit weight (g/plant) & $\begin{array}{c}\text { Fruit volume } \\
\left(\mathbf{c m}^{3} / \mathbf{f r u i t}\right)\end{array}$ & $\begin{array}{c}\text { Yield increase over } \\
\text { the control }(\mathbf{\%})\end{array}$ \\
\hline Control & $14.33^{\mathrm{a}}( \pm 3.27)$ & $58.49^{\mathrm{a}}( \pm 6.75)$ & $4.71^{\mathrm{a}}( \pm 0.81)$ & - \\
\hline $50 \% \mathrm{CFs}$ & $10.78^{\mathrm{a}}( \pm 2.00)$ & $52.87^{\mathrm{a}}( \pm 10.4)$ & $3.90^{\mathrm{a}}( \pm 0.94)$ & 13.10 \\
\hline $100 \% \mathrm{CFs}$ & $14.17^{\mathrm{a}}( \pm 1.85)$ & $96.04^{\mathrm{a}}( \pm 8.67)$ & $4.81^{\mathrm{a}}( \pm 0.51)$ & 74.05 \\
\hline $\mathrm{BFBFs}$ & $14.11^{\mathrm{a}}( \pm 3.94)$ & $89.09^{\mathrm{a}}( \pm 17.3)$ & $4.71^{\mathrm{a}}( \pm 0.37)$ & 50.42 \\
\hline $\mathrm{BFBFs}+50 \% \mathrm{CFs}$ & $14.77^{\mathrm{a}}( \pm 4.62)$ & $108.78^{\mathrm{a}}( \pm 17.0)$ & $6.39^{\mathrm{a}}( \pm 0.86)$ & 92.47 \\
\hline
\end{tabular}

(a)

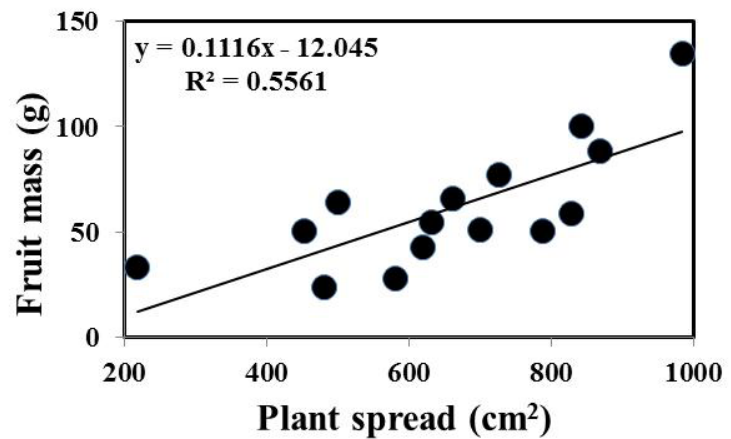

(b)

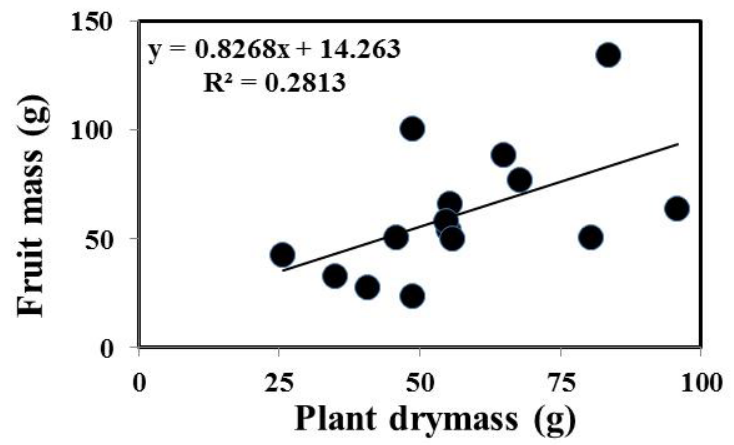

Figure 4: Relationships between fruit mass and (a) plant spread, and (b) plant dry mass.

\section{Profitability of strawberry production using BFBFs under field conditions}

The calculated net profits of strawberry under different treatments are given in Table 2. The net profit of BFBFs $+50 \%$ CFs treatment is LKR $164,722.00$ and it was only LKR $125,444.00$ of $100 \%$ CFs. The net profit increases of BFBFs $+50 \%$ CFs over the control and $100 \%$ CFs were $52 \%$ and $31 \%$, respectively. 
(a)

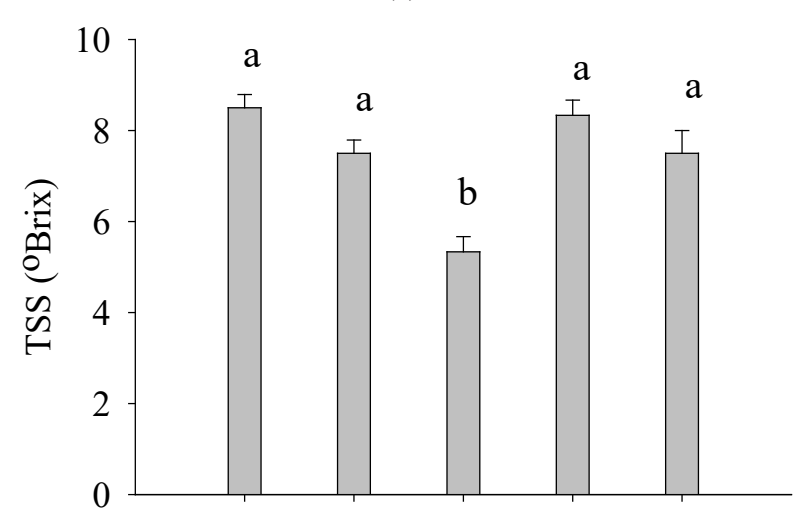

(c)

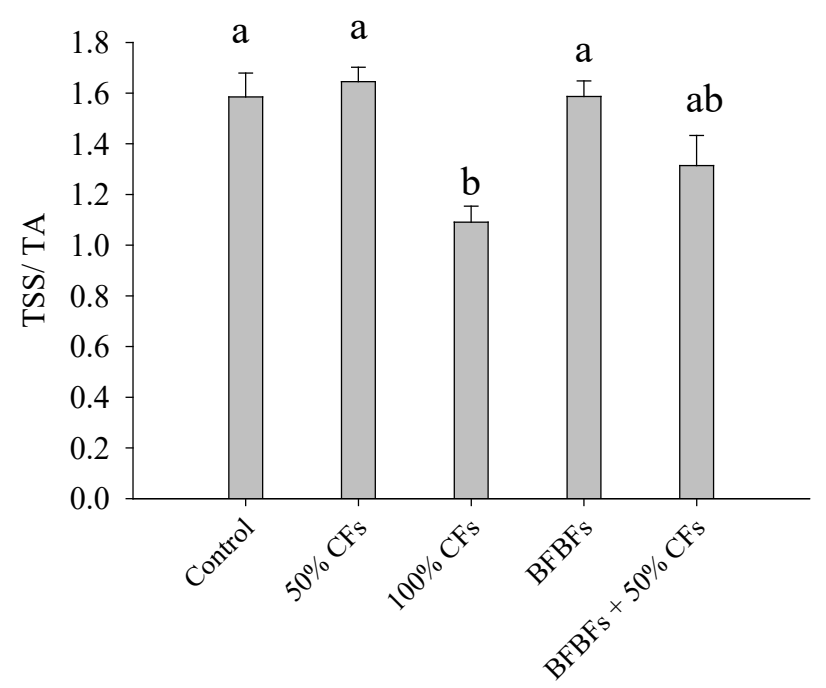

Treatment (b)

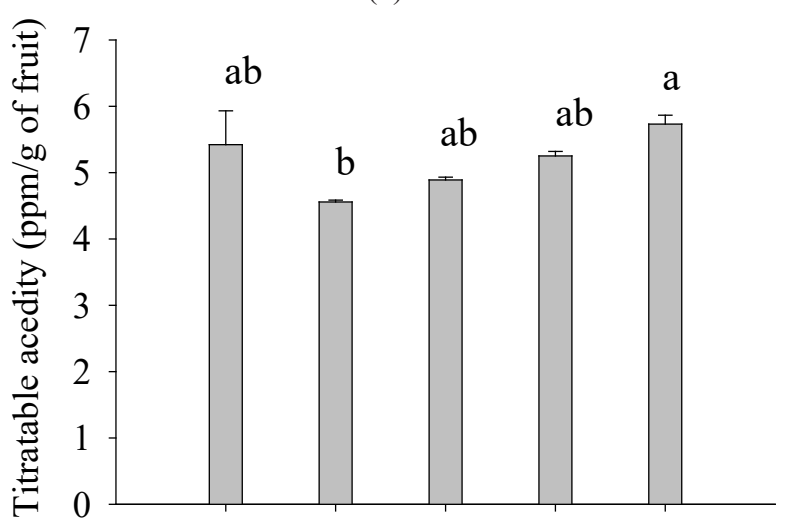

(d)

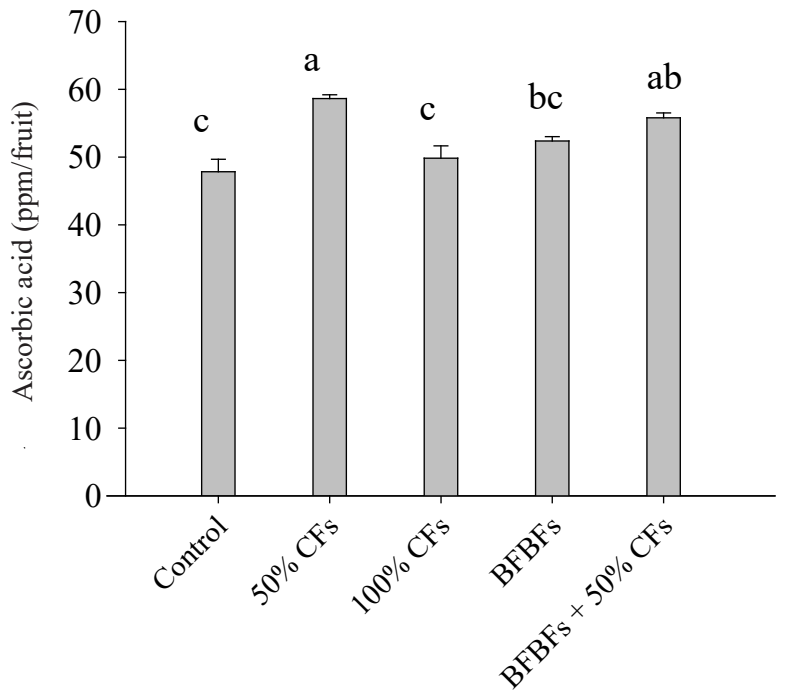

Treatment

Figure 5: Total Soluble Solids - TSS (a), Titratable acids - TA (b), TSS/TA ratio (c) and Ascorbic acid content (d) of strawberry fruits of different treatments. Bars with different letters indicate significant differences at $5 \%$ probability level. Vertical bars on the columns show standard errors of mean (SEM).

Table 2: Net profit of strawberry production for a 1000-plant strawberry crop

\begin{tabular}{|c|c|c|c|c|c|c|c|}
\hline Treatment & $\begin{array}{l}\text { CFs } \\
(\%)\end{array}$ & $\begin{array}{c}\text { Yield } \\
\text { (kg) }\end{array}$ & $\begin{array}{c}\text { Earning (LKR } \\
2,500(13.79 \$) / \mathrm{kg} \\
\text { of Strawberry) }\end{array}$ & $\begin{array}{c}\text { Approximate } \\
\text { Expenditure: fertilizer } \\
\text { + labor costs }(\mathrm{LKR})\end{array}$ & $\begin{array}{c}\text { Net profit } \\
\text { (LKR) }\end{array}$ & $\begin{array}{c}\text { Profit increase } \\
\text { over the } \\
\text { control (\%) }\end{array}$ & $\begin{array}{c}\text { Profit increase } \\
\text { over the } 100 \% \\
\text { CFs }(\%)\end{array}$ \\
\hline Control & 0 & 47.9 & $\begin{array}{c}119,750 \\
(660.32 \$) \\
\end{array}$ & $\begin{array}{c}11,111 \\
(61.27 \$) \\
\end{array}$ & $\begin{array}{c}108,639 \\
(599.05 \$) \\
\end{array}$ & - & -13.4 \\
\hline $50 \% \mathrm{CFs}$ & 50 & 48.9 & $\begin{array}{c}122,250 \\
(674.11 \$)\end{array}$ & $\begin{array}{c}14,778 \\
(81.49 \$)\end{array}$ & $\begin{array}{c}107,472 \\
(592.62 \$)\end{array}$ & -1.1 & -14.3 \\
\hline $100 \% \mathrm{CFs}$ & 100 & 62.0 & $\begin{array}{c}155,000 \\
(854.69 \$)\end{array}$ & $\begin{array}{c}29,556 \\
(162.98 \$)\end{array}$ & $\begin{array}{c}125,444 \\
(691.72 \$)\end{array}$ & 15.5 & - \\
\hline BFBFs & 0 & 57.0 & $\begin{array}{c}142,700 \\
(786.87 \$)\end{array}$ & $\begin{array}{c}11,111 \\
(61.27 \$)\end{array}$ & $\begin{array}{c}131,589 \\
(725.61 \$)\end{array}$ & 21.1 & 4.8 \\
\hline $\begin{array}{l}\text { BFBFs + } \\
50 \% \mathrm{CFs}\end{array}$ & 50 & 71.8 & $\begin{array}{c}179,500 \\
(989.79 \$)\end{array}$ & $\begin{array}{c}14,778 \\
(81.49 \$)\end{array}$ & $\begin{array}{c}164,722 \\
(908.30 \$)\end{array}$ & 51.6 & 31.3 \\
\hline
\end{tabular}

$1 \$=$ LKR 181.35 (02.01.2020); LKR = Sri Lankan Rupees

Labor cost: payment for field preparation, planting, weeding and watering. 


\section{DISCUSSION}

Many studies have been conducted in the past to evaluate the improvement of vegetative growth and yield of strawberry under chemical and biofertilizer applications. Amongst, Abu-Zahra and Tahboub (2008) showed an improved vegetative growth in strawberries under the chemical fertilizer application, but it delayed the onset of flowering. According to the present study, an improved vegetative growth and the highest yield were shown by plants treated with BFBF $+50 \%$ CFs (Figure 3 and Table 1). Previous studies have demonstrated improved yields in strawberry var. Chandler with the application of mono and co-culture based biofertilizers (Umar et al., 2009; Esitken et al., 2010; Pèsaković et al., 2013). However, the present results demonstrated the highest yield increase over the control $(92 \%)$ in comparison to previous studies (Table 3). Under experimental conditions of Esitken et al. (2010), the best monoculture biofertilizer for strawberry production was Bacillus OSU 142 strain with a yield increase of ca. 3\% over the control. Azotobacter improved the strawberry yield by $37 \%$ over the control, but it was in combination with 100\% chemical fertilizer dosage (Umar et al., 2009), highlighting no economic benefit of the practice. The findings of the present study in comparison to previous studies clearly showed the improved strawberry yield under the mixed-culture biofilms over conventional monoculture biofertilizers. Bandara et al., (2006) and Seneviratne et al., (2009) showed increased production of plant growth hormones like substances due to improved metabolic activities of fungal-bacterial biofilms over the monocultures of fungi or bacteria. Biofilm developed from Penicillium and Bradyrhizobium elkanii SEMIA 5019 generated higher number and concentrations of detectable monosaccharides than its respective monocultures (Zavahir and Seneviratne, 2007). Another biofilm developed from Azotobactor and Colletotrichum secreted carboxylic acids and carboxylic salts, which contributed significantly to enhance germination and plant height of lettuce (Herath et al., 2013). Thus, the improved growth and yield of strawberry in the present study may also have been attributed to the production of such bioactive compounds.
Biofilm mediated growth improvements have also been reported in other crops such as rice (Oryza sativa), tea (Camellia sinensis), wheat (Triticum aestivum) and in Anthurium (Anthurium andraeanum) (Seneviratne et al., 2009).

Sugars (TSS) and acid contents (TA) are considered as important quality attributes in strawberries. Results suggested that the addition of full dosage of chemical fertilizers can reduce the quality of fruits drastically (Figure 4). Thus, the addition of BFBFs with a reduced dosage of fertilizer can help maintain the quality of fruits in strawberry by increasing the aforementioned parameters, including vitamin $\mathrm{C}$ or ascorbic acid, which is an efficient oxygen radical scavenger with a strong antioxidant power (Zhang and Hamauzu, 2004). Strawberries have been reported to have the potential to contain a greater antioxidant capacity compared to other fruits (Giampieri et al., 2012). Citric acid, which determines TA, is the major organic acid in strawberries (Moing et al., 2001). In addition to citric acid, other organic acids such as malate, quinate, shikimate, succinate, and fumarate may also present in strawberries (Moing et al., 2001). Thus, the results of the present study suggested that $100 \% \mathrm{CFs}$ treated plants produced fruits with the lowest quality, whereas BFBF amended soils with greater microbial activity and resilience to stress improved the fruit quality. Jiménez-Gómez et al., (2017) also explained the ability of plant probiotic bacteria to enhance the quality of fruit and horticultural crops. However, the best treatment of the present study (BFBFs $+50 \%$ CFs) did not show significant fruit quality improvement, possibly due to the soil condition of the study. This warrants further evaluations under different soil conditions.

Previously, Singhalage et al., (2019) showed an increased profitability (152\% over the $100 \%$ CFs usage) of strawberry production with BFBFs containing Aspergillus sp. and Enterobactor sp. coupled with $40 \%$ of CFs in a pot experiment, further highlighting the promising potential of BFBFs in strawberry cultivation. The present study confirms that the BFBF between Aspergillus sp. and Enterobactor sp. with $50 \%$ of CFs can be introduced as the best fertilizer combination for strawberry production under

Table 3: Yield increases over the control under different bio- and chemical fertilizer applications, as reported in previous studies in comparison to the present study

\begin{tabular}{lcccc}
\hline Reference & $\begin{array}{c}\text { Type of } \\
\text { experiment }\end{array}$ & Control & Best performed treatment & $\begin{array}{c}\text { Yield increase over } \\
\text { the control (\%) }\end{array}$ \\
\hline Esitken et al., (2010) & Field & Without microbes & Bacillus OSU 142 & 2.8 \\
\hline Umar et al., (2009) & Field & $\begin{array}{l}\text { Without microbes or } \\
\text { chemical fertilizers }\end{array}$ & $\begin{array}{c}\text { Azotobacter } \\
+100 \% \text { of N as urea }\end{array}$ & 36.5 \\
\hline $\begin{array}{l}\text { Pèsaković } \text { et al., } \\
(2013)\end{array}$ & Green & $\begin{array}{l}\text { Without microbes or } \\
\text { chemical fertilizers }\end{array}$ & Klebsiella planticola & 34.0 \\
\hline Present study & Field & $\begin{array}{l}\text { Without microbes or } \\
\text { chemical fertilizers }\end{array}$ & $\begin{array}{c}\text { BFBF between } \text { Aspergillus } \text { sp. } \\
\text { and Enterobactor } \text { sp. }+50 \%\end{array}$ & \begin{tabular}{c} 
recommended chemical fertilizers \\
\hline
\end{tabular} \\
\hline
\end{tabular}


field conditions of the tested site.

\section{CONCLUSIONS}

At present, profitability and fruit quality are major concerns in the strawberry cultivation due to heavy chemical inputs. Present study demonstrates that the use of BFBF can address these issues successfully. The use of BFBFs has reduced the usage of recommended chemical fertilizers up to $50 \%$ while improving the fruit quality parameters. Thus, the usage of BFBFs together wih $50 \%$ of chemical fertilizer dosage can provide the growers a higher profit margin and consumers able to receive a high quality fruits. However, further studies are needed to test BFBF under variable soil and climatic conditions.

\section{ACKNOWLEDGEMENT}

The study was partially funded by University Grants Commission of Sri Lanka (UGC/ICD/RG/02/2012/10). Thus authors acknowledge the University Grant Commission of Sri Lanka.

We also acknowledge Dr. Mangalika Nugaliyadda, Officer In-charge, Seetha Eliya Agricultural Research Station for her facilitation to carry on the field experiments at Agricultural Research Station, Seetha Eliya.

\section{DECLARATION OF CONFLICT OF INTEREST}

The authors declare no competing interests.

\section{REFERENCES}

Abu-Zahra, T.R. and Tahboub, A.A. (2008). Strawberry (Fragaria $\mathrm{x}$ ananasa Duch) growth, flowering and yielding as affected by different organic matter sources. International Journal of Botany 4(4): 481-485. DOI: 10.3923/ijb.2008.481.485.

Jiménez-Gómez, A., Celador-Lera, L., Fradejas-Bayón, M. and Rivas, R. (2017). Plant probiotic bacteria enhance the quality of fruit and horticultural crops. AIMS Microbiology 3(3): 483-501. DOI: 10.3934/ microbiol.2017.3.483.

Ali, A., Abrar, M., Sultan, M.T., Din, A and Niaz, B. (2011). Postharvest physiochemical changes in full ripe strawberries during cold storage. The Journal of Animal and Plant Sciences 21(1): 38-41.

Bandara, W.M.M.S., Seneviratne, G. and Kulasooriya, S.A. (2006). Interactions among endophytic bacteria and fungi: effects and potentials. Journal of Biosciences 31: 645-650. DOI: 10.1007/BF02708417.

Dutta, S., Rani, T.S. and Podile, A.R. (2013). Root exudate-induced alterations in Bacillus cereus cell wall contribute to root colonization and plant growth promotion. PLoS ONE 8(10): e78369.

Esitken, A., Yildiz, H.E., Ercisli, S., Donmez, M.F., Turan, M. and Gunes, A. (2010). Effects of plant growth promoting bacteria (PGPB) on yield, growth and nutrient contents of organically grown strawberry. Scientia Horticulturae 124: 62-66. DOI:10.1016/J. SCIENTA.2009.12.012.

Giampieri, F., Tulipani, S., Alvarez- Suarez, J.M., Quiles, J.L., Mezzetti, B. and Battino, M. (2012). The strawberry: composition, nutritional quality, and impact on human health. Nutrition 28: 9-19. DOI : 10.1016/j. nut.2011.08.009.

Herath, H.M.L.I., Senanayeke, D.M.N., Seneviratne. G. and Bandara, D.C. (2013). Variation of biochemical expressions of developed fungal-bacterial biofilms over their monocultures and its effect on plant growth. Tropical Agricultural Research 24: 186-192.

Janagard, M.S., Raei, Y., Gasemi-Golezani, K. and Aliasgarzad, N. (2013). Soybean response to biological and chemical fertilizers. International Journal of Agriculture and Crop Sciences 5(3): 261-266.

Medley, M.J., Stewart, J.W.B. and Chauhanm, B.S. (1982). Changes in inorganic and organic soil phosphorus fractions induced by cultivation - practices and by laboratory incubations. Soil Science Society of America Journal 46(1): 970-976.

Moing, A., Renaud, C., Gaudillère, M., Raymond, P., Roudeillac, P. and Denoyes-Rothan, B. (2001). Biochemical changes during fruit development of four strawberry cultivars. Journal of American Society of Horticultural Science 126(4): 394-403. DOI: https:// doi.org/10.21273/JASHS.126.4.394.

Pešaković, M., Karaklajić-Stajić, Z., Milenković, S. and Mitrović, O. (2013). Biofertilizer affecting yield related characteristics of strawberry (Fragaria $x$ ananassa Duch.) and soil micro-organisms. Scientia Horticulturae 150: 238-243. DOI: 10.1016/j.scienta.2012.11.016.

Saharan, B.S. and Nehra, V. (2011). Plant growth promoting rhizobacteria: A critical review. Life Sciences and Medicine Research 21: 1-30.

Savci, S. (2012). An agricultural pollutant: chemical fertilizer. International Journal of Environmental Science and Development 3(1): 77-80.

Seneviratne, G. (2009). Collapse of beneficial microbial communities and deterioration of soil health: a cause for reduced crop productivity. Current Science 96: 633.

Seneviratne, G. (2012). Are we wrong in conventional approach of biocontrol? Current Science 103: 13871388.

Seneviratne, G. and Kulasooriya, S.A. (2013). Reinstating soil microbial diversity in agroecosystems: The need of the hour for sustainability and health. Agriculture Ecosystem and Environment 16: 181-182. DOI: https:// doi.org/10.1016/j.agee.2012.10.002.

Seneviratne, G., Jayasekara, A.P.D. A., de Silva, M.S.D.L. and Abeysekera, U.P. (2011). Developed microbial biofilms can restore deteriorated conventional agricultural soils. Soil Biology and Biochemistry 43: 1059-1062. DOI: https://doi.org/10.1016/j. soilbio.2011.01.026.

Seneviratne, G., Pevvast, G.A., Olfati, J.A. and Kariminia, A. (2009). Rhizobia as biofertilizers for mushroom cultivation. Current Science 96(12): 1559.

Singhalage, I.D., Seneviratne, G. and Madawala, H.M.S.P. (2019). Cultivated Strawberry (Fragaria $x$ ananassa) and Wild Strawberry (Duchesnea indica) rhizosphere associated microbes as inoculants to promote early vegetative growth of Strawberry. International Journal of Science and Research 8(5): 862-867. 
Singhalage, I.D., Seneviratne, G., Madawala, H.M.S.P and Wijepala, P.C. (2019). Profitability of strawberry (Fragaria ananassa) production with biofilmed biofertilizer application. Scientia Horticuturae 243: 411-413. https://doi.org/10.1016/j.scienta.2018.08.033.

Umar I., Wali, V.K., Rehman, M.U., Mir, M.M., Banday, S.A. and Bisati, I.A. (2010). Effect of subabul (Leucaena Leucocephala), urea and biofertilizer application on growth, yield and quality of strawberry cv. Chandler. Applied Biological Research 12: 50- 54.

Umar, I., Wali, V.K., Kher, R. and Jamwal, M. (2009). Effect of fym, urea and Azotobacter on growth, yield and quality of strawberry cv. Chandler. Notulae Botanicae Horti Agrobotanici Cluj-Napoca 37(1): 139-143. DOI: 10.15835/nbha3713110.

Yosefi, K., Galavi, M., Ramrodi, M. and Mousavi, S. R. (2011). Effect of bio-phosphate and chemical phosphorus fertilizer accompanied with micronutrient foliar application on growth, yield and yield components of maize (Single Cross 704). Australian Journal of Crop Science 5(2): 175-180. DOI:10.5539/jas.v3n4p22.
Zaitoun, S.T., Al-Ghzawi, A.A., Shannag, H.K. and AlTawaha, A.R.M. (2006). Comparative study on the pollination of strawberry by bumble bees and honeybees under plastic house conditions in Jordan valley. Journal of Food Agriculture and Environment 4(2): 237-240.

Zargar, M.Y., Baba, Z.A. and Sofi, P.A. (2008). Effect of $\mathrm{N}, \mathrm{P}$ and biofertilizers on yield and physicochemical attributes of strawberry (Fragaria annanosa L. Duch.). Agrothesis 6, 3-8.

Zavahir, J.S. and Seneviratne, G. (2007). Potential of developed biofilms in generating bioactive compounds. Research Journal of Microbiology 2: 397-401. DOI: 10.3923/jm.2007.397.401.

Zhang, D. and Hamauzu, Y. (2004). Phenolics, ascorbic acid, carotenoids and antioxidant activity of broccoli and their changes during conventional and microwave cooking. Food Chemistry 88: 503-509. DOI: https:// doi.org/10.1016/j.foodchem.2004.01.065. 